DR CHIARA FRASSI (Orcid ID : 0000-0002-7522-9905)

Article type : Paper

\title{
Did the "Autochthonous" European foreland of Corsica Island (France) experience Alpine subduction?
}

Maria Di Rosa ${ }^{1}$, Chiara Frassi ${ }^{1, *}$, Michele Marroni ${ }^{1,2}$, Francesca Meneghini $^{1}$, Luca Pandolfi ${ }^{1,2}$

${ }^{1}$ Dipartimento di Scienze della Terra, Università di Pisa, Italy

${ }^{2}$ Istituto di Geoscienze e Georisorse, CNR, Pisa, Italy

* Correspondence:

Chiara Frassi (Orcid: 0000-0002-7522-9905)

Tel.: +39 0502215781; email: chiara.frassi@unipi.it

Short title: HP-LT conditions in the Corsica European foreland

\section{Abstract}

Despite the important role played by the Sardinia-Corsica block in the reconstruction of the Western Mediterranean geodynamics, the extent of involvement of the "Autochthonous" European margin exposed in Corsica (France) (i.e., Hercynian Corsica) in the Alpine orogeny remains uncertain. Stratigraphic and sedimentological studies in the post-Variscan deposits on the Hercynian Corsica are scarce and even scarcer are the structural and metamorphic constraints. To face these uncertainties, we present new stratigraphic, structural and metamorphic data from the area of Razzo Bianco, Central Corsica, where a complete sequence belonging to the European

This article has been accepted for publication and undergone full peer review but has not been through the copyediting, typesetting, pagination and proofreading process, which may lead to differences between this version and the Version of Record. Please cite this article as doi: 10.1111/ter.12433

This article is protected by copyright. All rights reserved 
continental margin is exposed. Field and structural investigations demonstrate that the sequence represents the easternmost edge of the downgoing European plate. Metamorphic studies on the Eocene deposits indicate that the margin was buried at depth up to blueschist facies conditions and, subsequently, it was progressively exhumed mainly through the activation of oblique top-tothe NW shear zones.

Keywords: Hercynian Corsica, Alpine subduction, P-T-d path

\section{INTRODUCTION}

In Corsica Island (France), the "Autochthonous" European continental margin never underthrust below the Alpine orogenic wedge (e.g., Durand-Delga, 1984) is historically known as Hercynian Corsica. It consists of late Variscan granitoids, related host rocks, and PermoCarboniferous volcanic and volcaniclastic rocks (Rossi et al., 2015 and references therein) covered by early Jurassic and Eocene sedimentary covers. The oldest covers testify the carbonate platforms developed during Mesozoic on the European margin (i.e., the northern rim of the Ligure-Piemontese oceanic basin), whereas the youngest represent the foredeep deposits sourced from the innermost portion of the European margin itself (Cavazza et al., 2018; Ferrandini et al., 2010) and deposited during the Eocene collision between the European margin and the Alpine wedge-Adria microplate system.

As a consequence of the convergence-related processes leading this collision, small slices of the European margin were buried at depth along the eastward Alpine subduction slab up to blueschist facies metamorphic conditions and accreted to the overriding Alpine orogenic wedge (Malasoma and Marroni, 2007; Molli et al., 2006; Malasoma et al., 2006; Vitale Brovarone et al., 2012). During their exhumation, these continental slices were thrust westward onto the Hercynian Corsica forming the present-day architecture of the Alpine Corsica domain (Figure 1). West of this Alpine front, the only documented Alpine deformation is reported in French cartography (e.g., 1:50.000 geological maps, Amaudric du Chaffaut et al., 1983; Rossi and Rouire, 1980) as discontinuous and 100s m-thick brittle-ductile oblique shear zones affecting the late Variscan granitoids.

In this study, we present new structural and metamorphic data from an area located west of the Alpine front (Razzo Bianco area), where a complete sequence of the European continental margin (i.e., late Variscan granitoids, middle Jurassic carbonates and Eocene foredeep deposits) is 
exposed (Figures 1-3). We elaborated the first P-T-d path for the Hercynian Corsica suggesting that the "Autochthonous" European foreland exposed in the central portion of the island experienced Alpine polyphase deformation and metamorphism reaching greater depths than previously estimated.

\section{GEOLOGICAL SETTING}

The present-day architecture of the Corsica Island mainly results from the convergencerelated processes affecting the Ligure-Piemontese ocean since late Cretaceous. They initially produced an eastward intraoceanic subduction leading to the closure of this Tethyan oceanic branch and the consequent collision during (middle) Eocene-early Oligocene between the European continental margin and the Alpine wedge-Adria microplate system (e.g., Malavieille et al., 1998). During the continental collision, the not yet subducted Ligure-Piemontese oceanic lithosphere in its more southern branch started to be subducted toward the west below the European margin leading to the onset of the Apennine orogeny (Marroni et al., 2017 and reference therein). Accordingly, the geodynamic scenario drastically changed since the early Oligocene. This change produced a switch from compressive to extensional regime in Corsica, where sectors previously affected by compressional tectonics underwent extension. In addition, the retreat of the W-dipping slab produced the progressive opening of two back-arc basins: the Ligure-Provençal basin and the Tyrrhenian Sea (Figure 1). The formation of these two basins effectively isolated the Corsica-Sardinia block, freezing the Paleogene architecture of the European margin (Hercynian Corsica) and the Alpine wedge (Alpine Corsica), as well as their mutual relationships.

The boundary between Hercynian and Alpine Corsica is locally overprinted by a complex sinistral strike-slip faults system (i.e. Central Corsica Shear Zone - CCSZ; Central Corsica Fault Zone of Waters, 1990; Ostriconi Fault of Lacombe and Jolivet, 2005) (Figures 1 and 2). Although generally described as a crustal-scale structure, its significance, strain tensor components, relation with the Alpine shear zones and time activity (roughly constrained between late Eocene to early Oligocene; e.g., Di Rosa et al., 2017a; Gueydan et al., 2017; Lacombe and Jolivet, 2005; Maluski et al., 1973; Waters, 1990) have not be adequately constrained yet and still remain controversial.

The only available data concerning the area of Razzo Bianco are provided by the stratigraphic studies of the Eocene foreland deposits of Amaudric du Chaffaut (1980) and Ferrandini et al. (2010). Amaudric du Chaffaut (1980) also documented 100s m-thick sinistral brittle-ductile Alpine shear zones in the late Variscan granitoids that have been recently interpreted by Di 
Vincenzo et al., (2016) as strike-slip shear zones active during a progressive middle to late Eocene burial event coeval with the emplacement of the Alpine wedge.

\section{METHODS}

Through detailed field mapping and mesoscopic structural analyses, we defined three new members in the Eocene deposits described by Ferrandini et al., (2010) (Venaco Fm.; see Figures 2 and 3) and we documented a pervasive ductile deformation in granitoids west of the Alpine front (Figure 2). Using X-ray compositional maps on one sample collected in the Eocene foredeep deposits, we strictly linked the composition of chlorite and phengite end-members to microstructural domains (S1 and S2 foliation) (Figure 4a). Pressure and temperature estimations are so calculated for each chlorite-phengite pairs grew along the S1 and S2 foliations using XMapTools software (Lanari et al., 2014) and ChlMicaEqui software (Lanari, 2012) (Figure 5) providing the first P-T-d path to the west of the Alpine front (see Supplementary material for detailed methods description, analytical details and P-T estimates).

\section{RESULTS}

The entire sequence exposed in the Razzo Bianco area records a polyphase deformation history (Figures 2, and 4-6) consisting of two ductile phases (D1-D2) that were lately partially reworked by a brittle-ductile event (D3). Since the structures related to the D1 phase were strongly transposed by the S2 foliation, only rare relicts of S1 foliation were documented within D2 microlithons in the Eocene metapelites. S1 foliation is marked by syn-kinematic growth of chlorite + phengite + albite + quartz (Figures 4 and 5a). In the selected sample, chlorites grew along the S1 foliation (Chl1) have a Si content between 2.50 and 2.65 a.p.f.u., with a XMg ranging from 0.48 and 0.64 (Figure 4c). In particular, the content of XMg decreases within the chlorite crystals moving from core (Chlla) to the rim (Chllb). Phengites grew along the S1 foliation (Phg1) has Si content between 2.90 and 3.40 a.p.f.u. and $\mathrm{Al}$ content between 2.00 and 2.40 a.p.f.u. (Figure 4c). The Tschermak substitution is activated moving away from the core. This trend is confirmed by the shift from celadonite (Phg1a) to muscovite (Ph1b) end-members (Figure 4b). We constrained the P-T equilibrium conditions of the D1 phase at 0.98-1.34 $\pm 0.2 \mathrm{GPa}$ and $226-362 \pm 30^{\circ} \mathrm{C}$ (Figure 6 and Table S1).

D2 produced map-scale open folds associated to a penetrative axial plane foliation (S2) that locally evolved to a mylonitic foliation defining 1 to $30 \mathrm{~s}$ m-thick anastomosed D2 shear zones 
affecting both the metagranitoids and the sedimentary covers. They show a top-to-the NW oblique sense of shear and they represent the along-strike continuation of the shear zone investigated by Di Vincenzo et al. (2016) few kms SW of Razzo Bianco (Figure S1).

In the metagranitoids, $\mathrm{S} 2$ foliation is marked by weakly elongated quartz polycrystalline aggregates and thin layers of white micas (Figure 5e) whereas in the Eocene pelites, it is a continuous foliation marked by chlorites and phengites (Figures $4 \mathrm{a}$ and $5 \mathrm{~d}$ ). In the sample used for thermobaric investigations, chlorites grew along the S2 foliation (Chl2) have a Si content ranging between 2.72 and 2.90 a.p.f.u. and XMg ranging between 0.48 and 0.55 (Figure 4b). The ditriocthaedric substitution thus causes the change from a daphnite-rich chlorite, during the D1 phase, to a progressively sudoite-rich chlorite, during the D2 phase. This change implies a progressively decrease of the temperature conditions (Vidal and Parra, 2000). Phengites grew along the S2 foliation (Phg2) has Si and Al content ranging between 3.25 and 3.65 a.p.f.u. and between 1.93 and 2.25 a.p.f.u. (Figure $4 b$ ), respectively. The activation of the pyrophyllite substitution from Phg1b to Phg2 indicates that the transition from D1 to D2 phase is characterized by a progressively decrease of pressure (Vidal and Parra, 2000). Couples of syn-kynematic sudoite-rich chlorite and pyrophyllite-rich phengite are in equilibrium at $0.84-0.26( \pm 0.2) \mathrm{GPa}$ and 293-169 $( \pm 30){ }^{\circ} \mathrm{C}$ (Figure 6 and Table S1). Deformation temperatures obtained using mechanical twins parameters in calcite crystals $\left(\mathrm{T}>200{ }^{\circ} \mathrm{C}\right.$; see Supplementary material for method description and analytical details), and quartz microstructures $\left(\mathrm{T}<420^{\circ} \mathrm{C}\right.$; Law, 2014 and references therein) (Figure 5e) are consistent with these temperatures.

D3 phase produces $\mathrm{cm}$ - to $\mathrm{m}$-sized open to close recumbent and asymmetric E-verging F3 folds (Figure 5f) associated to an S3 crenulation cleavage. No metamorphic blastesis is associated with this phase. The last recorded event is a system of strike-slip faults than can be correlated with the activity of the CCSZ (Figures 2 and 6).

\section{DISCUSSION}

Fission Track data (Danišik et al., 2007) suggest that during the Eocene the entire sequence of the easternmost sector of the Hercynian Corsica, where Razzo Bianco area is located, was perturbed by a heating event under $\mathrm{T}=60-300^{\circ} \mathrm{C}$, and consequently covered by Eocene foredeep deposits and/or Alpine wedge for a minimum thickness of $\sim 2.0-2.5 \mathrm{~km}$. Since $\sim 33 \mathrm{Ma}$, the wedge underwent orogenic collapse, that boosted the onset of exhumation by erosional (and tectonic) denudation (Figure 6). According to Danišik et al. (2007) the tectonic switch from compression to 
extension reflects the isostatic rebound, consequence of the slab break-off of the Alpine subduction and the eastward rollback of the new Apennine subduction zone.

In contrast, Ferrandini et al. (2010) indicate that the Eocene foredeep deposits (Venaco Fm.) escaped the Alpine deformation and metamorphism that instead affected the underlying Variscan basement and Mesozoic sedimentary cover. According to these authors, the Priabonian age of the uppermost portion of the Venaco Fm., (member of Cardo) constrains the Alpine deformation to before the late Priabonian-early Oligocene.

More recently, Di Vincenzo et al. (2016) suggested that the Variscan basement in Central Corsica reached a minimum depth of $18 \mathrm{~km}$ during a late Eocene tectonic burial stage. They constrained the syn-kinematic growth of white micas in the strike-slip shear zones mapped by Amaudric du Chaffaut et al. (1983) in the Hercynian Corsica (Figure S1) documenting three generations of white micas: an older (not much earlier than $46 \mathrm{Ma}$ ) Si-poor white micas overgrown by a younger (37-35 Ma) syn-shear white micas, stable at $\geq 300{ }^{\circ} \mathrm{C}$ and $0.52-0.58 \mathrm{GPa}$, and by later (33-32 Ma) white micas incipiently re-equilibrated during exhumation (Figure 6).

In this paper, we documented that the complete sequence of the easternmost edge of the European downgoing plate exposed in the Razzo Bianco area acquired a polyphase deformation (D1-D3) and metamorphism (up to blueschist facies conditions: $\mathrm{T} \approx 240-300{ }^{\circ} \mathrm{C}$ and $\mathrm{P} \approx 1.30-1.38$ GPa) during its burial and consequent exhumation, both occurred below the Alpine wedge (Figure 6).

In this sector of the island, the Alpine tectonics is constrained between the age of the youngest foredeep sediments involved in the subduction (middle to late Eocene; Durand-Delga, 1978; Egal, 1992; Bezert and Caby, 1988) and the age of the deposits sealing the CCSZ and the main tectonic contacts (middle Burdigalian; Cavazza et al., 2007 and references therein) (Figure 6). More in detail, the burial phase of the Razzo Bianco European sequence (not documented in this study) should have occurred after the youngest foredeep deposits involved in the deformation (middle to late Eocene) and before the D1 phase (i.e., the beginning of exhumation) (Figure 6).

Unfortunately, the accurate age of foredeep sediments remain uncertain. Even if middle-late Lutetian age was frequently documented in northern Corsica (Amaudric du Chaffaut et al., 1985; Rossi et al., 1994), Bartonian (41.2-37.8Ma) (Bezert and Caby, 1988) and even Priabonian (37.833.9Ma) (Ferrandini et al., 2010) ages were found. As a consequence, the burial stage of Razzo Bianco cannot be adequately constrained without new detailed biostratigraphic investigations in the Eocene deposits. In addition, the timing of exhumation (i.e., D1 phase) is controversial. 
Considering that phengites grew along the S1 foliation (i.e., Phg1b in Figure 4b) has a composition fully compatible with that of the syn-shearing white micas dated by Di Vincenzo et al. (2016), the D1 phase can be regarded as developed already during the late Eocene. However, Rossetti et al. (2015) have provided the evidence that the burial and exhumation history of the Tenda massif (Figure 1), i.e. the easternmost edge of the European continental margin, were achieved during the late Eocene - early Oligocene time before the extensional tectonics related to orogenic collapse.

Despite these timing uncertainties, we speculate that the exhumation of the downgoing margin started as consequence of the isostatic rebound related to the Alpine slab break-off (D1 phase) and continued through progressive localization along oblique top-to-the NW shear zone (D2 phase).

The lack of syn-kynematic phyllosilicates indicates that D3 phase occurred at shallower structural levels $\left(\mathrm{T}<150-200^{\circ} \mathrm{C}\right.$ ) (Figure 6). In analogies with studies conducted in the Alpine Corsica (e.g., Malasoma and Marroni, 2007; Rossetti et al., 2015), we interpreted the D3 phase as the expression of the extensional regime resulting by the Alpine slab break-off, subduction reversal and consequent eastward retreat of the Apennine slab (Figure 6). Finally, analogously to what described in the Corte and Cima Pedani areas (Di Rosa et al., 2019a,b), strike-slip faults of the CCSZ overprint the F3 folds. As a consequence, its activity in this portion of Corsica should be considered as starting since the early Oligocene, and probably linked mainly to the late Oligocene - early Miocene counter-clockwise rotation of the Corsica-Sardinia block and LigurianProvençal rifting.

The only time constraint available for the Eocene covers exposed in the Razzo Bianco area is the Apatite Fission Track age obtained by Danišik et al. (2007) (Figure S1). These authors suggested that at $\sim 23 \mathrm{Ma}$ the margin passed through the isotherms $110-70^{\circ} \mathrm{C}$. We propose that this transit could testify the orogenic collapse of Corsica Island associated with the rifting and opening of the Ligurian-Provencal Basin.

\section{CONCLUSIONS}

Our structural and metamorphic investigations indicate that the "Autochthonous" European sequence exposed in the Razzo Bianco (metagranitoids, middle Jurassic marble and Eocene covers) represents the easternmost edge of the downgoing continental margin buried at depth (up to the blueschist facies conditions) below the Alpine wedge and then exhumed at shallower structural levels mainly through the activity of (D2) oblique top-to-the NW shear zones. We 
suggest that to individuate the real "undeformed" European foreland, future works should investigate the structures and the metamorphism even in the westernmost sectors of the Hercynian Corsica.

\section{Acknowledgements}

This study was supported by the University of Pisa (PRA project) and by the SIMP, SGI, SOGEI and AIV. We are grateful to Olivier Vidal, Valentina Batanova and Valerie Magnin (IsTerre, Grenoble) for their assistance during the EPMA analysis. We also thank the anonymous reviewers and the associate editor V. Pascucci whose constructive and critical comments improved the manuscript.

\section{Data Availability Statement}

The authors confirm that the data supporting the findings presented in this paper are available within the article and/or its supplementary materials.

\section{REFERENCES}

Amaudric du Chaffaut, S., 1975. L'unité de Corte: un témoin de "Piémontais externe" en Corse? Bulletin de la Société géologique de France, 7, 739-745.

Amaudric du Chaffaut, S., 1980. Les unités alpines a la marge orientale du massif cristallin corse. Doctoral dissertation, Université Pierre et Marie Curie-Paris 6.

Amaudric du Chaffaut, S., Bonin, B., Caron, J. M., Conchon, O., Rossi, P.,Bimbier, A., Damiani, L., Dominici, R., Heetveld, H., and Rouire, J., 1985. Carte Géologique de la France (1/50000), feuille Venaco (1114). BRGM Orléans.

Amaudric du Chaffaut, S., Caron, J. M., Jauzein, A., Bonin, B., Rossi, P., Conchon, C., and Perthuisot, J. P., 1983. Carte Geologique de la France (1/50000), feuille Venaco (111a). BRGM, Orléans.

Bezert P., and Caby, R., 1988. Sur l'age post-bartonien des événements tectonométamorphiques alpins en bordure orientale de la Corse cristalline (Nord de Corte). Bolletin Societe Géologi France, 4, 965-971. 
Cavazza, W., Gandolfi , G., and Paganelli, L., 2018. Reconstructing the Alpine orogenic wedge and its foreland basin: The petrologic transition from Cretaceous passive-margin to Eocene foreland sedimentation in northern Corsica (France). In: Tectonics, Sedimentary Basins, and Provenance: A Celebration of William R. Dickinson's Career (R.V. Ingersoll, T.F. Lawton, and S.A. Graham eds.). Geological Society of America, Special Paper, 540, 741-757.

Cavazza W., DeCelles, G., Fellin M. G., and Paganelli, L., 2007. The Miocene Saint-Florent Basin in northern Corsica: stratigraphy, sedimentology, and tectonic implications. Basin Research, 19, 507-527.

Danišik, M., Kuhlemann, J., Dunk1, I., Székely, B., and Frisch, W., 2007. Burial and exhumation of Corsica (France) in the light of fission track data. Tectonics, 26, TC1001.

Di Rosa, M., De Giorgi, A., Marroni, M., and Vidal, O., 2017a. Syn-convergence exhumation of continental crust: evidence from structural and metamorphic analysis of the Monte Cecu area, Alpine Corsica (Northern Corsica, France). Geological Journal, 52, 919-937.

Di Rosa, M., De Giorgi, A., Marroni, M., and Pandolfi, L., 2017b. Geology of the area between Golo and Tavignano Valleys (Central Corsica): a snapshot of the continental metamorphic units of Alpine Corsica. Journal of Maps, 13, 644-653.

Di Rosa, M., Frassi, C., Meneghini, F., Marroni, M., Pandolfi, L., and De Giorgi, A., 2019a. Tectono-metamorphic evolution in the European continental margin involved in the Alpine subduction: new insights from the Alpine Corsica, France. Comptes Rendus Geoscience, Online view, https://doi.org/10.1016/j.crte.2018.12.002.

Di Rosa, M., Meneghini, F., Marroni, M., Hobbs, N., and Vidal, O., 2019b. The exhumation of continental crust in collisional belts: insights from the deep structure of Alpine Corsica in the Cima Pedani area. The Journal of Geology, 127, 263-288.

Di Vincenzo, G., Grande, A., Prosser, G., Cavazza, W., and DeCelles, P. G., 2016. 40Ar/39Ar laser dating of ductile shear zones from central Corsica (France): Evidence of Alpine (middle to late Eocene) syn-burial shearing in Variscan granitoids. Lithos, 262, 369-383.

Durand-Delga, M., 1984. Principaux traits de la Corse Alpine et correlations avec les Alpes Ligures. Memorie della Società Geologica Italiana, 28, 285-329.

Durand-Delga, M., 1978. Corse. Guide Géologique Regionaux. Masson ed.

Egal, E., 1992. Structures and tectonic evolution of the external zone of Alpine Corsica. Journal of Structural Geology, 14, 1215-1228.

Ferrandini, J., Ferrandini, M., Rossi, P., and Savary-Sismondini, B., 2010. Définition et datation 
de la formation de Venaco (Corse): dépot d'origine gravitaire d'age Priabonien. Comptes Rendus Geoscience, 342, 921-929.

Frost B.R., Frost C.D., 2013. Essentials of Igneous and Metamorphic Petrology. Cambridge University Press.

Gueydan, F., Brun, J.-P, Phillippon, M., and Noury, M., 2017. Sequential extension as a record of Corsica Rotation during Apennines slab roll-back. Tectonophysics, 710-711, 149-161.

Lacombe, O., and Jolivet, L., 2005. Structural and kinematic relationships between Corsica and the Pyreneeses-Provence domain at the time of the Pyrenean orogeny. Tectonics, 24, TC1003, doi: 10.1029/2004TC001673.

Lanari, P., 2012. The Matlab-based ChlMicaEqui software (unpublished).

Lanari, P., Vidal, O., De Andrade, V., Dubacq, B., Lewin, E., Grosch, E., and Schwartz, S., 2014. XMAPTOOLS: a MATLAB c -based program for electron microprobe X-ray image processing and geothermobarometry. Computers and Geosciences, 62, 227-240.

Law, R. D., 2014. Deformation thermometry based on quartz crystal fabrics and recrystallization microstructures: a review. Journal of Structural Geology, 66, 129-161.

Malasoma, A., Marroni, M., Musumeci, G., and Pandolfi, L., 2006. High pressure mineral assemblage in granitic rocks from continental units, Alpine Corsica, France. Geological Journal, 41, 49-59.

Malasoma, A., and Marroni, M., 2007. HP/LT metamorphism in the Volparone Breccia (Northern Corsica, France): evidence for involvement of the Europe/Corsica continental margin in the Alpine subduction zone. Journal of Metamorphic Geology, 25, 529-545.

Malavieille, J., Chemenda, A., and Larroque, C., 1998. Evolutionary model for the Alpine Corsica: mechanism for ophiolite emplacement and exhumation of high-pressure rocks. Terra Nova, 10, 317-322.

Maluski, H., Mattauer, M., and Matte, P.H., 1973. Sur la presence de decrochement alpins en Corse: Comptes Rendue Acad. Science, 276, 709-712.

Marroni, M., and Pandolfi, L., 2003. Deformation history of the ophiolite sequence from the Balagne Nappe, northern Corsica: insights in the tectonic evolution of the Alpine Corsica. Geological Journal, 38, 67-83.

Marroni, M., Meneghini, F., and Pandolfi, L., 2017. A revised subduction inception model to explain the Late Cretaceous, double-vergent orogen in the pre-collisional western Tethys: Evidence from the Northern Apennines. Tectonics, 36, 2227-2249. 
Molli, G., 2008. Northern Apennine-Corsica orogenic system: an updated overview. In: Siegesmund S., Fugenschuh, B., Froitzheim, N. (eds.) Tectonic Aspects of the AlpineDinaride-Carpathian System. Geological Society London Special Publication, 298, 413-442.

Molli, G., Tribuzio, R., and Marquer, D., 2006. Deformation and metamorphism at the eastern border of Tenda Massif (NE Corsica): a record of subduction and exhumation of continental crust. Journal of Structural Geology, 28, 1748-1766.

Rossetti, F., Glodny, J., Theye, T., and Maggi, M., 2015. Pressure temperature deformation- time of the ductile Alpine shearing in Corsica from orogenic construction to collapse. Lithos, 218-219, 99-116.

Rossi P., Cocherie, A. and Fanning, C. M., 2015. Evidence in Variscan Corsica of a brief and voluminous Late Carboniferous to Early Permian volcanic-plutonic event contemporaneous with a high-temperature/low-pressure metamorphic peak in the lower crust. Bulletin de la Société géologique de France, 186, 171-192.

Rossi, P., and Rouire, J., 1980. Carte géologique de la France au 1:250000. M. Ind. Bur. Rech. Géol. Min. Serv. Geol. Nat., Orléans.

Rossi, P., Durand-Delga, M., Caron, J. M., Guieu, G., Conchon, O., Libourel, G., and Loye-Pilot, M., 1994. Carte Geologique de la France (1/50,000), feuille Corte (1110). BRGM, Orléans.

Vidal, O., and Parra, T., 2000. Exhumation paths of high-pressure metapelites obtained from local equilibria for chlorite-phengite assemblage. Geological Journal, 35, 139-161.

Vitale Brovarone, A., Beyssac, O., Malavieille, J., Molli, G., Beltrando, M., and Compagnoni, R., 2012. Stacking and metamorphism of continuous segments of subducted lithosphere in a high-pressure wedge: The example of Alpine Corsica (France). Earth Science Reviews, 116, $35-56$.

Vitale Brovarone, A., and Herwartz, D., 2013. Timing of HP metamorphism in the Schistes Lustrés of Alpine Corsica: new Lu-Hf garnet and lawsonite ages. Lithos, 172-173, 175-191.

Vitale Brovarone, A., Picatto, M., Beyssac, O., Lagabrielle, Y., and Castelli, D., 2014. The blueschist-eclogite transition in the Alpine chain: P-T paths and the role of slow-spreading extensional structures in the evolution of HP-LT mountain belts. Tectonophysics, $\mathbf{6 1 5}, 96-$ 121.

Walker, J.D., Geissman, J.W., Bowring, S.A., and Babcock, L.E., compilers, 2018. Geologic Time Scale v. 5.0: Geological Society of America, https://doi.org/10.1130/2018.CTS005R3C. (C)2018 The Geological Society of America. 
Waters, C. N., 1990. The Cenozoic tectonic evolution of Alpine Corsica. Journal of Geological Society, London, 147, 811-824.

\section{SUPPORTING INFORMATION}

Additional supporting information may be found online in the Data Repository section at the end of the article. 


\section{Figures}

\section{Figure 1}

Sketch map of the Weastern Mediterranean, simplified geological sketch map of the Corsica Island and location of the study area. Remains of the Alpine orogenic prism are exposed in the north-eastern portion of the island (i.e. Alpine Corsica domain) whereas the rest of the island represents the "Autochtonous" foreland of the European continental margin (Hercynian Corsica domain) (modified after Amaudric du Chaffaut, 1975; Di Rosa et al., 2017a, b; 2019a, b; Marroni and Pandolfi, 2003; Molli, 2008; Vitale Brovarone and Herwatz, 2013 and references therein; Vitale Brovarone et al., 2014).

\section{Figure 2}

Detailed geological map, geological cross-section and equal area, lower hemisphere Schmidt projections of the main structural elements documented in the Razzo Bianco area (planes are projected as poles). Location of photographs shown in Figure 5 and samples used for structural and metamorphic investigation are also shown. The main foliation (S2 foliation) was documented in all the lithotypes described in the area. It is oriented N-NE-S-SW and generally dips toward ESE. It is associated to a NW-SE trending stretching lineation plunging $60-70^{\circ}$ toward SE.

\section{Figure 3}

Stratigraphic log and related field pictures of the European margin sequence exposed in Razzo Bianco area. The log includes a basement represented by Permo-carboniferous metagranitoids that are disconformably covered by Mesozoic to Tertiary metasediments. The base of the metasediments is represented by metalimestones (Metalimestone Fm.), of possible early Jurassic age. The pristine stratigraphic relationships between the Metalimestone Fm. and the metagranitoids are testified by the occurrence, at base of the metasediments, of normal graded beds with a coarse-grained base made up of a matrix-supported metabreccias containing clasts of quartz, granitoids and rare quarzites in a carbonate matrix. The Metalimestone Fm. as well as the metagranitoids are unconformably covered by an almost 200 -thick fine-upward sequence that consists, from bottom to the top, of the Metacarbonate breccia Fm., the Polygenic metabreccia Fm. and the Metasandstone and metasiltstone Fm. The entire sequence corresponds to the Lutetian- 
Bartonian member of Uboli of the Venaco Fm. (Ferrandini et al., 2010). Time scale after Walker et al. (2018).

\section{Figure 4}

Geometrical relations and microchemical composition of white micas grew along the S1 and S2 foliations in the sample used to P-T estimates (see Figure 2 for location and Supplementary material for methods description, analytical details and P-T estimates). (a) Backscattering SEM image representing D1 and D2 micro-domains. (b) Compositional map elaborated from X-ray maps of (a) with XMapTools (Lanari et al., 2014). Chl1a, Chl1b, Chl2 and Phg1a, Phg1b Phg2 represent progressive events of metamorphic blastesis of chlorite (Chl) and phengite (Phg) grew along the S1 and S2 foliation. In particular, (c) chlorite and phengite compositional diagrams and ternary diagrams showing the proportion of their end-members. DT: Tschermak substitution; TK: di-trioctahedral substitution; P: pyrophyllite substitution; Clin: clinochlore; Daph: daphnite; Sud: sudoite; Am: amesite; Ms: muscovite; Prl: pyrophyllite; Cel: celadonite.

\section{Figure 5}

Structures documented in the European continental margin exposed in Razzo Bianco area. (a) Photomicrograph of relics of S1 foliation (S1) preserved in the Polygenic metabreccia Fm. (plane polarized light). (b) Elongated calcilutite clasts parallel to the S2 foliation (S2) in the Metacarbonate breccia Fm. (c) In the Paleozoic metagranitoids, the S2 mylonitic foliation (S2) is marked by stretched and weakly asymmetric quartz and feldspar crystals pointing to a top-to the W sense of shear. (d) Top-to-the W D2 shear zone in the Polygenic metabreccia Fm. S2: S2 foliation; C: shear plane. (e) Photomicrograph of deformed Paleozoic metagranitoids. The S2 foliation (S2) is marked by syn-kinematic white mica (Wm) and quartz showing dynamic intracrystalline deformation, bulging recrystallization and incipient sub-grain rotation recrystallization. Locally, it is affected by grain boundary area reduction. Feld: feldspar (cross polarized light). (f) F3 fold affecting the Sandstone and siltstone Fm. (S2: S2 foliation; A.P.3: F3 axial plane). S3 foliation is mainly produced by rigid rotation of phyllosilicates crystals and it is locally marked by irregular films of insoluble material produced by pressure solution mechanisms.

\section{Figure 6}


A comparison of the tectonic evolution deduced from apatite fission track thermochronology results (Danišik et al., 2007) and ${ }^{39} \mathrm{Ar}-{ }^{40} \mathrm{Ar}$ dating (Di Vincenzo et al., 2017) performed in the areas surrounding Razzo Bianco (Figure S1), with the new tectono-metamorphic evolution (including a P-T-d path) proposed in this study for the European margin exposed in the central Corsica. The different size of coloured squares in the P-T-d path reflects the error in the P and T estimates. Stability field of the metamorphic facies are from Frost and Frost (2013).

Abbreviations: EBs: epidote blueschist facies; LBs: lawsonite blueschist facies; PGs: pumpellyite greenschist facies; Gs: greenschist facies; LAC: lawsonite-albite-chlorite; PP: prehnitepumpellyite facies; and Z: zeolite facies. The Paleogene geodynamic framework of western Mediterranean area is also shown. Time scale after Walker et al. (2018). 


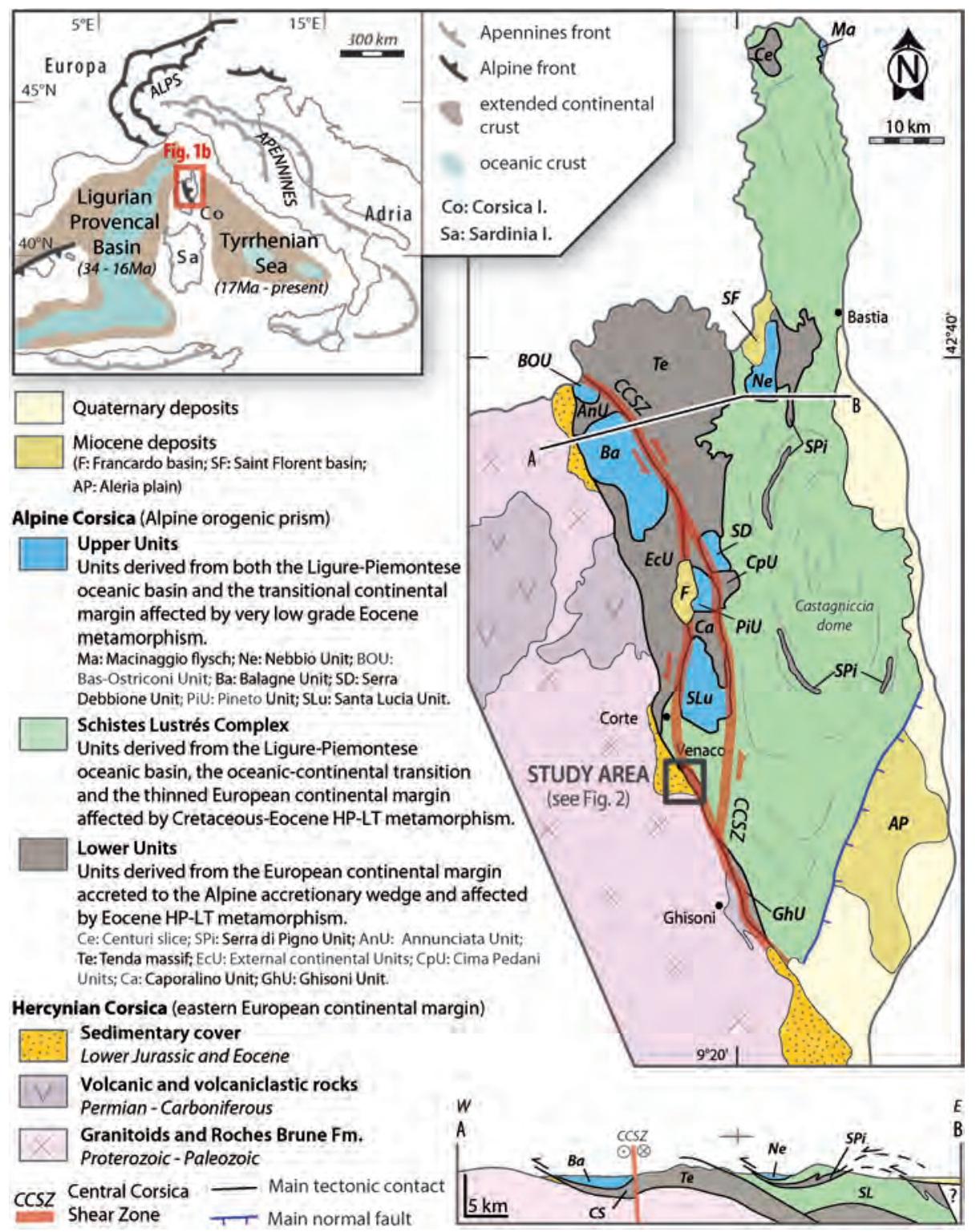

ter_12433_f1.tif 


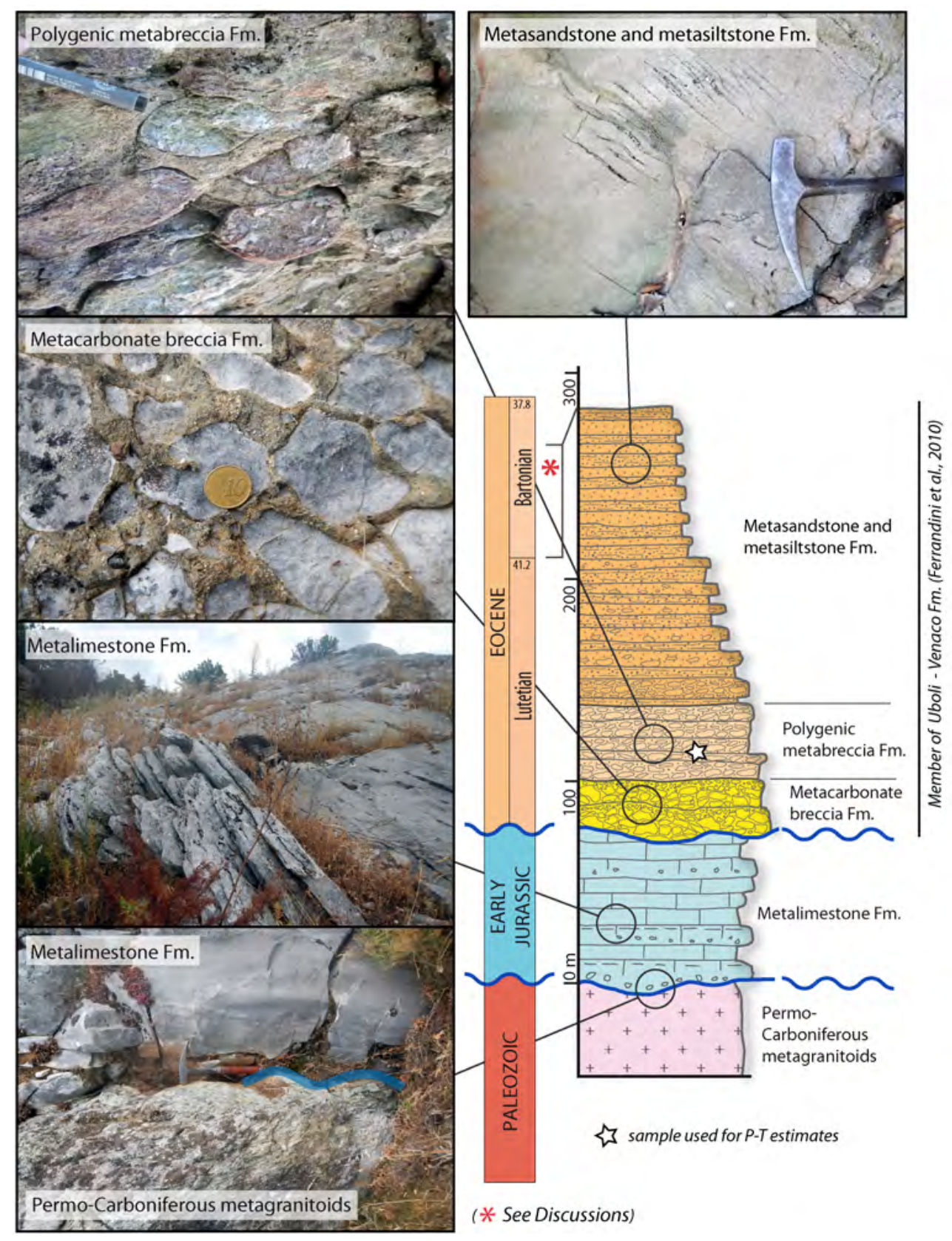

ter_12433_f3.tif 

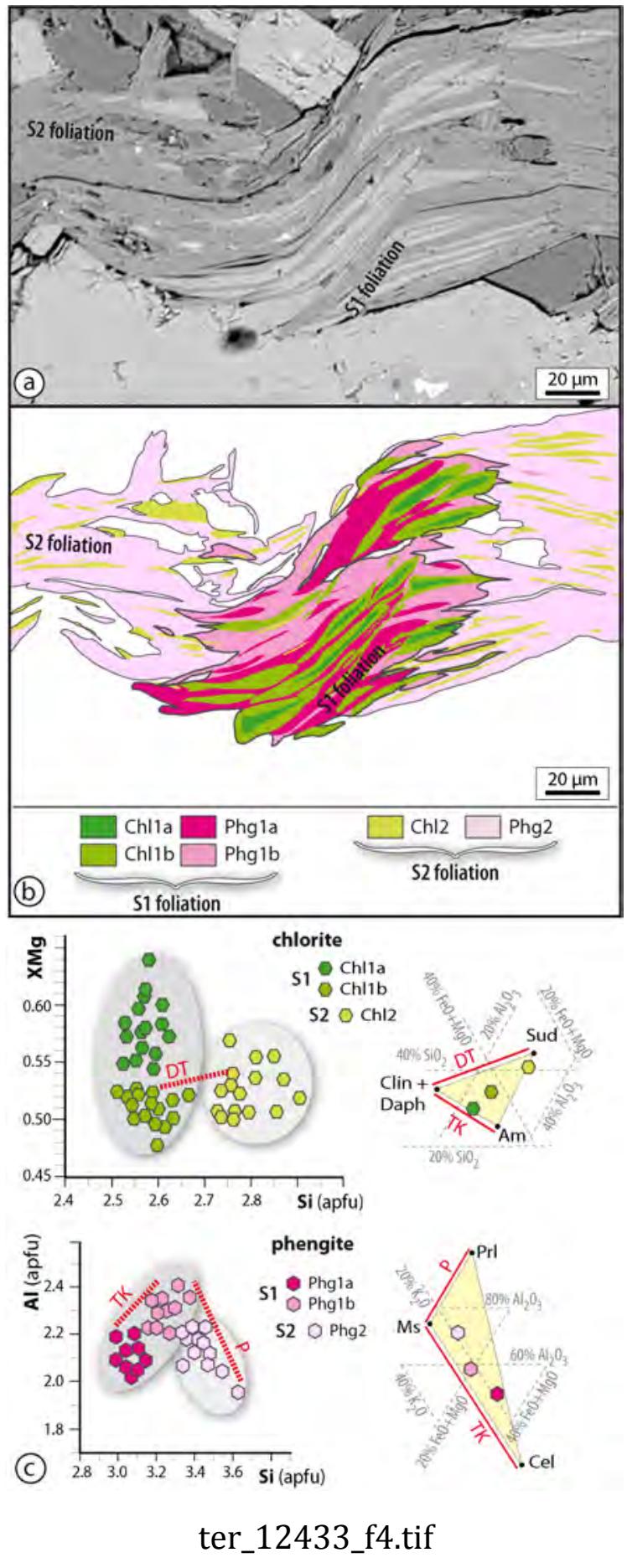

This article is protected by copyright. All rights reserved 

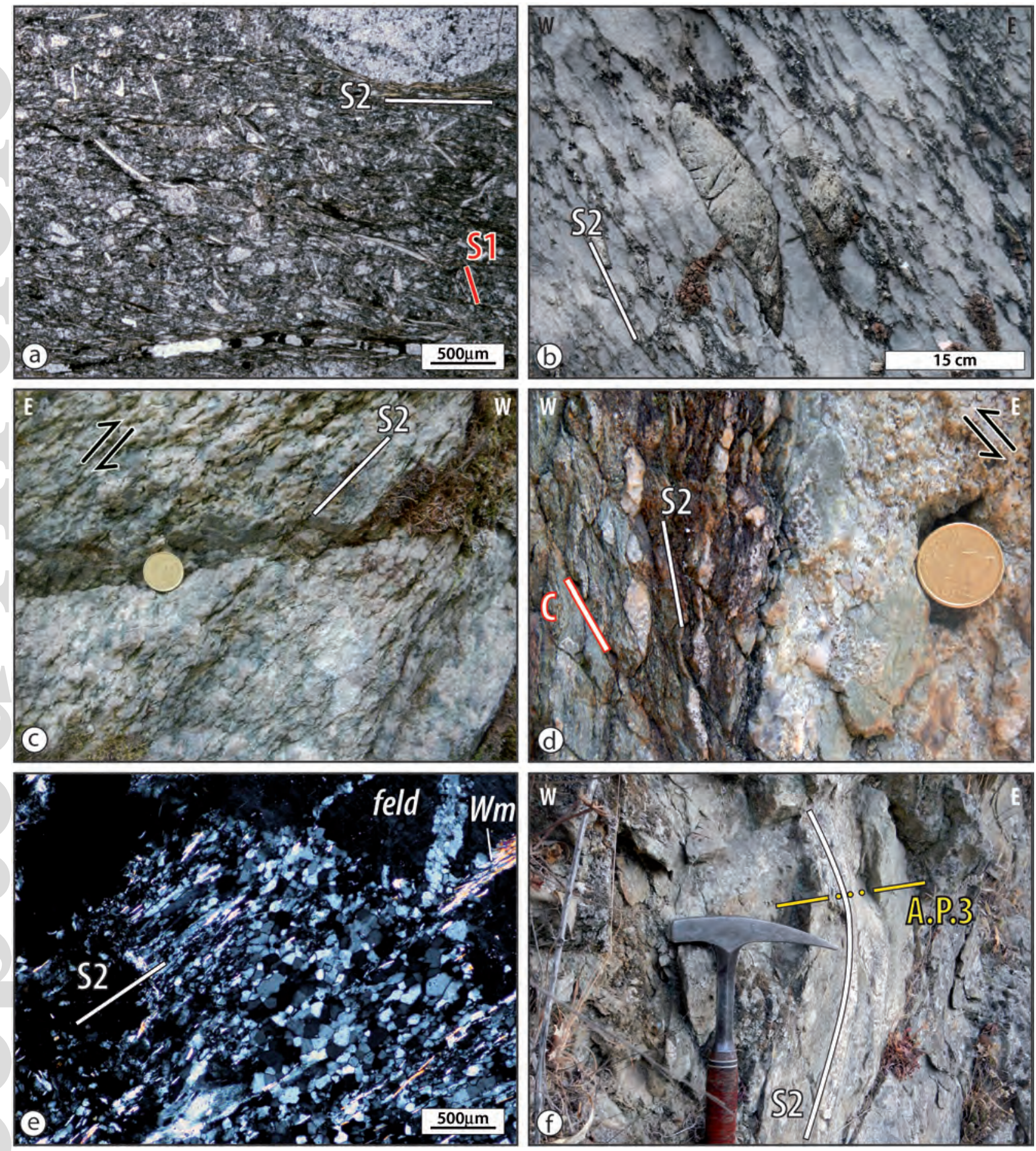

ter_12433_f5.tif

This article is protected by copyright. All rights reserved 


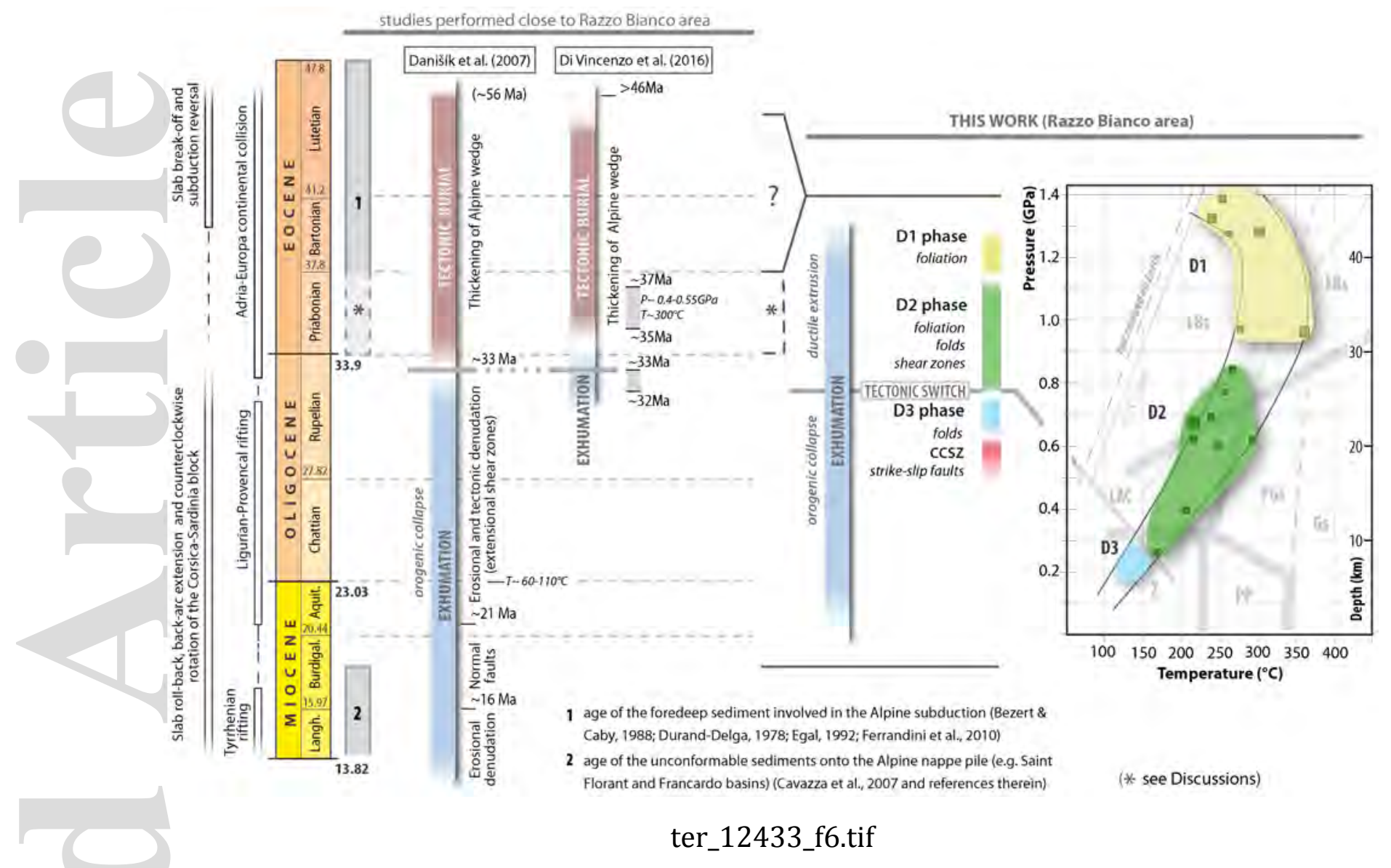

This article is protected by copyright. All rights reserved 